\title{
Founding Time and the Growth of Firms
}

\author{
G. R. Chandrashekhar
}

R. Srinivasan

$T$

This research recognizes the importance of the founding conditions of a firm. A new construct, Founding

Time (FT) has been conceptualized, measured, and validated to represent one of the founding conditions of a firm. FT is then used to understand the phenomena of growth of firms.

The impact of FT on the growth of a firm has been examined.This examination reveals that there is a certain zone of FT, which seems to result in high firm growth rates. This research also establishes that there is an optimum for the FT of a firm.

A multimethod approach has been used which includes econometric modeling and case studies. This approach has allowed us to triangulate the results of FT in this research.

Growth and evolution of firms has fascinated management thinkers for more than a century and various scholars have proposed many theories on the topic of growth of the firm during the last century or so. A literature review on growth of the firm was conducted to understand and evaluate the various contributions toward enhancing the understanding of the growth process. The Industrial Organization (IO) schools of thought seem to have prevailed for almost a century ever since Edgeworth proposed the Neo Classical model of growth in 1881. The Neo Classical theory and the Bain type IO seem to have evoked responses from Schumpeter and the economists of Chicago school which were then codified as separate schools of thought. Oliver Williamson, building on the work of Ronald Coase, developed further the Transaction Cost Economics (Williamson 1989). Each one of these schools of thought had an influence on the evolution of the Resource Based View of the firm (Wernerfelt 1984).

Edith Penrose's classic work on the growth of firms (Penrose 1959; 1984), which evolved in parallel to the IO schools of thought, examined the growth process of the firms and addressed three key issues related to the growth of the firm. In Penrose's view firms are organizations of people that have administrative control over productive assets and whose fields of operations are not limited to particular markets. Thus, the growth of this sort of firm is qualitatively different from the simple increase of output of a neo-classical "firm."

The general rules governing this sort of an organization may be thought of as:
1. Constant returns to scale in the long run,

2. The possibility of diversification, and

3. Increasing costs of growth

Penrose $(1959 ; 1984)$ integrated all three concepts to form a sustained criticism of the earlier static Neo Classical theory, in which a firm was a construct with a cost curve and a demand curve which functioned with the underlying logic of input combination and optimal pricing. Penrose's work influenced either directly or indirectly the evolution of subsequent schools of thought including the Resource-based view, diversification and diversification strategy, and spillover models to name some.

Penrose's work seems to have motivated other researchers such as Baumol (1962, c.f. Slater 1979), Marris (1964, c.f., Slater, 1979) and Gander (1991) to examine various aspects related to growth of the firm. Gander (1991) examined the impact of Managerial Diseconomies of Scale proposed by Penrose, on the growth of firms, in his empirical work, while Marris (1964, c.f., Slater 1979) examined the impact of Owner-Manager Dichotomy on the growth of the firm. However, modeling the growth of firm has seen both a constant return to scale approach based on the Neo Classical production function as well as on decreasing returns to scale approach, such as the one adopted by Jovanovic (1982).

Historically, empirical findings that firm growth is roughly independent of firm size have led to the development of a number of IO theories in which Gibrat's law is taken as an assumption or as a desirable implication. Gibrat's law proposes that firms grow in a random manner without any specific relation to their respective sizes. Theoretical work in the 1980s on industry evolution has emphasized the importance of learning on firm growth and changes in market structure. Jovanovic (1982) and Lippman and Rumelt (1982) examine the implications of the assumption that firms can learn about their efficiencies from realizations of costs. Jovanovic's (1982) model predicts that firm growth decreases with firm age when firm size is held constant.This version of Jovanovic's model also assumes that output is a decreasing convex function of managerial inefficiency.

The study of new ventures is increasingly viewed as an important aspect of organizational research (c.f., Bamford, Dean, and McDougall 2000). However, new ventures fail at an alarming rate and hence as a result some management researchers have focused on the determinants of new ven- 
ture performance (Carter et al. 1994; McDougall and Robinson 1990; c.f., Bamford, Dean, and McDougall 2000).

Bamford, Dean, and McDougall (2000) have examined new bank start-ups from three perspectives: external control, strategic choice, and resource. They found that a set of initial founding conditions explained performance variations of the banks they studied. They also found that the impact of initial founding conditions appeared to diminish over time for at least two of the three performance measures they had considered. This research attempts to understand in more precise terms as to how long does a firm take to found itself, by which time it has an established business model, a set of customers, a set of employees, and a set of investors.

The organization effectiveness measurement literature seems to suggest that the intuitive choice of earnings as an ultimate criterion of effectiveness is endemic to policy empirical research in spite of numerous articles, books and rhetoric on the multiple goal character of effectiveness (Kirchhoff 1977:353). We have defined a concept called Founding Time (FT) in this research and validated it using data from the Indian Information Technology Services (IT) industry. The concept of FT defined by us could be a comprehensive firm measure that would indicate that point in time in the evolution of a firm, from which a firm becomes more professional and self-sustainable. Hence, from an organizational effectiveness measurement point of view, the concept of FT provides a multidimensional measure of the firm that in many ways indicates the success of a firm from its inception.

Thus, FT could be construed as the first measure of organizational effectiveness of a firm from its inception. Understanding and unraveling the FT of a firm forms the motivation of this research.

\section{The Concept of FT of a Firm}

Organization theorists, beginning with the seminal work by Stinchcombe (1965, c.f. Bamford, Dean, and McDougall 2000), have advocated that new firms are imprinted at the time of founding and that this imprinting has lasting effects on the subsequent strategy, structure, and performance of those firms. Stinchcombe emphasized the role of social structure on the forms of new firms, arguing that their forms were temporally stable due to the institutionalization at the time of founding (Bamford, Dean, and McDougall 2000).

Similarly, Pennings (1980:254) viewed organization birth as the "overriding factor in molding and constraining the organization's behavior during subsequent stages of its life cycle." Boeker (1988, c.f., Bamford, Dean, and McDougall 2000) and Boeker (1999) emphasized the critical importance of initial founding conditions in determining the strategy that new firms pursue throughout their lives and concluded that firms are set on a course at founding.
Stinchcombe and other researchers who have investigated new firms remain silent on the duration for which a firm would retain its founding imprint, or be influenced by its founding imprint. We propose FT as that time duration, after which a founding imprint has relatively less impact on the subsequent evolution of a firm. This is also characterized by a firm displaying rapid economic growth around and after the FT with stable levels of profitability and consistent returns on the capital employed.

Our case study based research indicates that three of the firms we have observed so far (Infosys Technologies Limited, Trigent Software Limited, and Prologix) grew out of their founding imprints around the time they displayed a rapid growth in sales with consistent levels of profits and returns. These firms formalized their review and planning process and involved many others in the decision-making process, which was hitherto limited to the founders and a few others in the respective organizations. Thus, our measure of FT, which is predicated on sales, profits and returns, seems to identify an important stage of evolution of a firm wherein a firm has founded itself and is poised for subsequent sustainable and rapid growth.

Economists, on the other hand, have approached the firm growth phenomena in a different manner. Leibenstein (1966, $1968,1969,1972$ ) advocated the concept of X-Efficiency to understand and describe the phenomena of firm growth. According to Leibenstein (1969:600), "Firms do not produce on the outer bounds of their production possibility surface but well within it." Thus, he defines "X-inefficiency as the degree to which actual output is less than the maximum output for a given set of inputs." He also defines increases in outputs for the same inputs as increases in X-Efficiency. Leibenstein (1969) concludes that firms frequently do not take advantage of many opportunities to decrease costs per unit or to increase output with existing inputs. He is, however, silent on the duration it may take for a firm to reach the state of full X-Efficiency (i.e., to operate either on the production possibility surface or very close to it) from inception.

We propose that FT as conceptualized and measured by us, is that duration which elapses from the inception of a firm, around or after which a firm reaches a state of full XEfficiency and operates as close as it possibly could to its production possibility surface. We have measured this by observing peak sales growth with stable levels of profitability and returns on capital. Conceptually, we have proposed the FT as follows:

$$
\begin{gathered}
\mathrm{FT}=\mathrm{f} \\
\text { Employed }, \text { Profits before tax }\}
\end{gathered}
$$

\section{Conceptual Derivation of FT}

The spillover models of growth form the basis of this research. 
Romer (1986) introduced the concept of technology to the Neo Classical growth model. Conceptually, this could be considered as:

Output (of a firm) $=\mathrm{f}$ \{Capital, Labor \& Technology $\} \quad 1.3 .1$ this could then be expanded as

Output $=\mathrm{f}\{($ Founding Capital + Accrued Capital $)$, Labor, Technology\}

1.3 .2

or

Output $=\mathrm{f}\left\{\right.$ Founding Capital, $\left(\right.$ Changes in Capital $^{1}+$ Profit after $\operatorname{Tax}^{2}$ ), Employees, Research and Development (R \& D) investment\}

Accrued capital would include increases in the capital and also the profits from operations that are added to the reserves of the firm. The technology factor would be adequately represented by the R\&D investment made by the firm.

In this research, output and growth of a firm is measured by the sales and changes in sales revenue of a firm.Thus, 1.3.3 becomes

Sales $=\mathrm{f}\{$ Founding Capital, Changes in Capital, Profit after tax, Employees, R \& D Spend\}

1.3 .4

A firm would operate close to its production possibility curve if its total output were to be maximized; in this case if its sales revenues were to be maximized.The combinations of outputs for a given set of inputs, which maximize profits, also maximize revenues.

Hence, it is concluded that maximizing sales revenues for a given set of inputs (as shown in the right-hand side of equation 1.3.4) would lead a firm to operate on its production possibility curve. Thus, we argue that maximization of sales revenues for a set of constant inputs defines that point in time of a firm which indicates its operations on its production frontier.

If a firm's inputs were held constant (i.e., total capital employed, profit after tax, employees, R\&D spending were constant for a certain period, and sales revenue were maximized in that period), it would indicate that a firm is operating on its production frontier. FT is that period of time which elapses after which a firm operates on its production frontier for the first time since inception, for a given set of inputs: $\mathrm{FT}=\mathrm{f}\{$ Sales, Capital Employed, Profit after Tax, Employees,

R \& D Spend

However, decisions involving hiring of employees and investment in $R \& D^{3}$ depend on the performance of a firm, which is sales growth in our case. It would be sufficient to consider that $\mathrm{F}=\mathrm{f}$ \{Sales, Profit after Tax, Capital Employed $\}$.

Capital employed is likely to be of different order for different industries; hence return on capital employed would allow this conceptualization to be generalized across different industries.
FT $=\mathrm{f}\left\{\right.$ Sales, Profit after Tax, Return on Capital Employed $\left.{ }^{4}\right\}$

The basis of the conception in this research is that a firm exhibits sustainable sales growth after it has founded itself in all aspects of business. In this research it is proposed to observe sustainable peaks of sales growth in a firm's evolution and mark that time corresponding with the highest sustainable peak as the FT of a firm. Sustainable growth would require stable levels of profits and returns while a firm is on a high sales growth path which provides the basis for our conception.

This proposed concept of FT bridges two foundational concepts, the first one being that of "founding imprint" as advocated by Organization Theory researchers starting from the seminal work of Stinchcombe (1965, c.f., Bamford, Dean, and McDougall 2000) and the other being that of " $\mathrm{X}$ Efficiency," another seminal work by Leibenstein (1966).

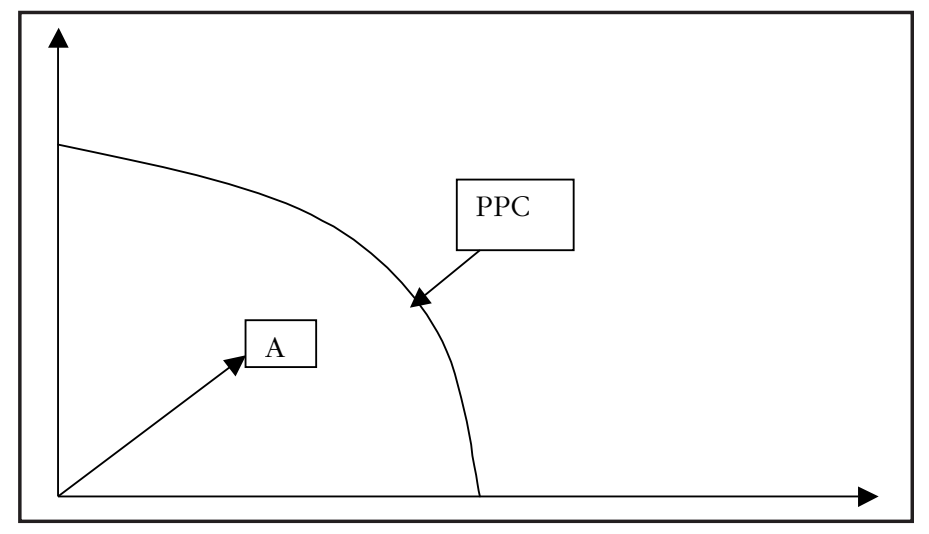

Figure 1.

Production Possibility Curve - PPC

\section{Definitions}

\section{Firm}

A firm is defined as a combination of resources it possesses and processes it engenders toward meeting a set of objectives. Resources and processes are considered disengaged and combine to address the objectives of the firm. This definition of a firm has been influenced by Dierickx and Cool (1989) and has been arrived at after examining the various definitions of firms in the literature.

\section{Growth}

Growth of a firm has been considered as an increase in sales revenue of a firm, since percentage change in sales is a key indicator of performance for small and new firms (Brush and Vanderwerf 1992). Sales revenue is a product of the price of a service and the amount of units of service rendered. An increase or decrease in price alone could change the sales revenue. It is also possible that fluctuations in foreign exchange rates between the Indian Rupee and other foreign currencies could affect the net sales recorded. 
However, in this research we shall consider the total net sales of each firm only for the purpose of measuring growth of a firm. With the context of this research being Indian IT service firms, it is expected that increase in number of employees of a firm each year shall ensure that there is an increase in the total number of units of service rendered. However, not all employees contribute to the revenue earning activity of a firm as the capacity utilization of the Indian IT service firms has seldom been 100 percent. Hence, net sales revenues shall be the measure of growth of a firm.

\section{Founding Time (FT)}

FT is measured as that time elapsed between the year of incorporation of the firm and the first sharp upward inflexion of sales revenue of the firm since inception. Any sharp inflexion of sales revenue in the first three years (robustness check have been done for two and four years) since inception is to be ignored for the purpose of defining the FT, especially as there could be an abnormal growth in sales from a small revenue base. This sharp upward inflexion should be followed by stable or rapid growth for at least three years and there should be no negative growth following the upward inflexion for three years. The firm in consideration should also have either stable or increasing profits during this period. Such a state would uniquely define the completion of the founding phase of a firm based on which the FT would be measured. The founding completion year (FCY) is the year immediately preceding the year in which there is an observed sharp upward inflexion of sales. Thus, FT $=$ Founding Completion Year - Year of Incorporation +1 .

The underlying assumptions about the FT concept includes the fact that a firm has generated the needed assets for its business according to a business plan and has also evolved a business model for its various activities addressing specific customer segments, by the time of the completion of the founding phase.The concept of FT, though measured on the time dimension, actually covers almost all aspects of a firm's initial development and is not only an elegant measure but also an insightful one.

The concept of FT is strategic in nature and transcends any operational measure used to understand businesses or portfolios, such as break-even points, payback periods, etc. In the course of founding, a firm may pursue only a single business opportunity or may enter multiple businesses and/or even exit some of them. The more operational measures used to understand business portfolios cannot be used to measure the FT, hence the need for a new definition and measure.

\section{Method for Estimating the FT'}

The steps for estimating FT are:

1. Find the year of incorporation of a firm in any form- proprietorship, partnership, limited liability company, etc. (the year in which a firm was incorporated and not when it was listed on stock exchanges).

2. Prepare a table containing the sales, profits (PAT), and return on capital employed (ROCE) data of the firm for around two decades starting from the year of incorporation.

3. In the table develop a column for sales growth rate, year by year.

4. Observe the growth rate from the year of incorporation and observe all sharp upward surges in the sales growth rate of the firm.

5. Upward surges should be distinctly different from the preceding and succeeding years (the distinction could range from $20 \%$ to $150 \%$ or higher).

6. Initial upward surges in the sales growth for a period of three years are to be avoided, as they would be from a low base of revenue and may or may not be sustainable

7. Thus FT of a firm cannot be less than or equal to three years.

8. Choose the highest upward surge in sales growth rate from all other such surges.

9. The firm should have recorded positive growth after this year of upward surge for a period of three (2-4) years; if not, discard this upward surge and choose the next highest upward surge.

10. Examine the profits of the firm during the year of this upward surge. The profits of the firm should either be stable or growing for a period of three years after the year of the upward surge; if not, discard this upward surge and choose the next highest upward surge.

11. The ROCE of the firm should be positive during the year of the upward surge chosen and for a period of three years after.

12. Founding Completion Year (FCY) is the year immediately preceding the year in which there was a sharp upward surge and which satisfied other conditions mentioned above.

13. FT = Year of Incorporation - Founding Completion Year +1 .

14. If two peaks are separated only by a period of two years, then the more prominent peak should be considered.

15. If the prominent peak in ( $n$ ) is unstable, then the lower peak of the two should not be considered and instead some other peak should considered.

16. If the firm is not founded by the above method, then $F$ $=$ Age of the firm +1 . The assumption here being that a firm which has not been founded so far may be founded in the subsequent year. 


\section{Research Design and Methodology}

The objectives of this research are to measure FT and to validate the concept of FT.

The measurement of FT was done by using the method outlined in the previous section. The validation of FT was done by using the following regression model:

$\mathrm{G}=\mathrm{B}_{0}+\mathrm{B}_{1}{ }^{*} \mathrm{~F}+\mathrm{B}_{2}{ }^{*} \mathrm{FT}^{2}+\mathrm{V}$

where:

G equals growth rate of firms (sales growth, year on year)

F is FT of firm (measured in number of years)

$\mathrm{B}_{0} \quad$ represents the intercept term of the above regression model

$B_{1} \quad$ is the coefficient of the $F$

$\mathrm{B}_{2}$ equals the coefficient of $\mathrm{F} 2$

$\mathrm{V}$ is random (stochastic) term

We chose the above model because we wanted to investigate and establish if there was an optimum for the FT which resulted in superior growth of the firm. If the linear term $\mathrm{F}$ had a positive coefficient and the squared term $\mathrm{F}^{2}$ had a negative coefficient, there would be an optimum for the FT.

In addition to the econometric model developed, case studies were used to understand the founding phenomena in three different firms and in this process triangulate the results of this research.

\section{Data and Sample}

This research requires a longitudinal study of firms from their inception. The choice of industry is predicated on a relatively new industry rather than an older one.The Indian Information Technology Services (IT) industry is a relatively new one having originated in the 1980s and come of age in the 1990s. Thus, the Indian IT sector shall be the focus of this research.

The origin of this industry can be traced back to December 19, 1986, when the government of India promulgated the software policy, and analysis of this policy is available in the January 1987 issue of Dataquest which is the oldest and probably the most respected of the Indian Information Technology magazines. In 1987 , only two Indian firms were involved in software exports from India: Tata Consulting Services (TCS) and Tata Unisys Ltd (now Tata Infotech). Total software exports from India were estimated to be around 600 MINR (Million Indian National Rupee).
The National Association of Software and Service Companies (NASSCOM) was formed in 1988. It has since become the apex organization for all software and service firms in India and also other information technology-related firms. The structure of the Indian IT industry is outlined in Table 1.

NASSCOM's membership of Indian IT firms totals more than 600 , or 95 percent of revenue of the Indian IT firms.

\section{Data Selection Method}

A specific sample was constructed for this research. The challenge this presented was to cull the relevant data from various directories and track them consistently over the years. The other challenge was the choice of the industry. Since the Indian IT Services industry was a nascent and emerging industry during the 1980 s and 1990s, there were numerous changes of ownerships, name changes, and mergers all of which had to be carefully tracked.

The databases accessed were NASSCOM'S Indian Software Directory (1992-2003). Data obtained from this process was then cross-validated with the data from the annual surveys of DATAQUEST (1987-2004). Annual reports of firms, drawn from Insight - Corporate Database, wherever available and necessary were used to complete the sample construction.

The following method was used to arrive at a final sample of 48 firms for this research.

1.All firms considered belong to the private sector as that is the focus of this research.

2.All joint ventures considered also involve private firms from the Indian side (e.g., BAeHAL, a joint venture between British Aerospace and Hindustan Aeronautics Limited, is not part of this study; whereas, Mahindra-British Telecom, a joint venture between Mahindra's and British Telecom is part of this study).

3. Multinational firms with their Indian subsidiaries or operations have not been considered in this research (e.g., IBM, Novell, Digital, etc.).

\begin{tabular}{|c|c|}
\hline \multicolumn{2}{|c|}{ Table 1. Industry Structure of Indian IT Firms } \\
\hline Annual Sales Revenue (2001) & No. of Firms \\
\hline Above \$ 200 Million & 5 \\
\hline \$100 Million - \$200 Million & 5 \\
\hline$\$ 50$ Million - \$100 Million & 15 \\
\hline$\$ 20$ Million - \$50 Million & 27 \\
\hline \$10 Million - \$20 Million & 55 \\
\hline$\$ 2$ Million - \$10 Million & 220 \\
\hline Below \$ 2 Million & 2,483 \\
\hline 1 US $\$=45.86$ Indian National Rupee & (Source: www.rbi.org.in, 12-Oct-04.) \\
\hline Source: NASSCOM 2001. & \\
\hline
\end{tabular}


4. Offshore hubs of firms based in the United States, such as Metamor, IMR, SYNTEL, Mastech/Igate, have not been considered.

5. IT firms which originated in other areas such as training (Aptech, NIIT), hardware (PCL Mindware, HCL Consulting/Technologies, DCM Data Systems, Microland), and other businesses (WIPRO, DDE ORG), whose reporting of software and services results were not distinctly clear, have not been considered in this research.

6.All firms considered were in business during a major portion of the period 1995-2004.

7. Firms founded after 1997 have not been considered, as there would not be at least an eight-year data view available for these firms.

8. All firms chosen have or had their own websites.

9.All firms considered are in the business of commercial software development; firms operating in specific niches of process and industrial automation software and any other real-time/embedded software have not been considered in this research.

10. Firms in the areas of data capture, desktop publishing, publishing, CD-ROM developers, and multimedia (e.g., Pentafour) are not part of this research.

11. In-house IT/IS departments of firms and groups do not form a part of this research.

12. Firms in the specific areas of voice communication-related activities are not part of this research.

13. Firms in the specific areas of anti-virus software and document management software are not part of this research.

14. Firms with inconsistent reporting over the period of the study have not been considered (e.g., Datamatics, Mafatlal Consultancy Services, Log-In Systems, Kanbay Software).

15. Firms involved in the specific areas of map making and geographic information systems are not part of this research.

16.All firms in various types of Business Process Outsourcing have been excluded from this research

17. Firms involved only in DSP, embedded systems, firmware development, and hardware design [e.g., Silicon Automation (Sasken)] are not part of this research.

18. Firms primarily involved in hardware manufacturing (in Telecom and CNC areas) who also manufacture software are not part of this research.

\section{Sample Description}

The 48 firms selected through the 18-step method are classified in Table 2 .

The sample in Table 2 represented about 50 percent of the entire Indian IT services industry by sales revenue in 2004 and about 52 percent of the entire industry in 2003.

\section{Results and Discussions}

The concept of FT was examined for the Indian IT services firms. The results of this examination are presented below. Table 3 lists the firms examined in this research.

The square term has been used to mathematically arrive at the turning point in the relationship which is indicative of the optimum.A model based on Ordinary Least Squares (OLS) estimates of growth predicated on $\mathrm{F}$ and $\mathrm{F}$ Square suggests an optimum FT which results in high firm growth rates. The estimated optimum is about eight years for this sample, after which the growth rates taper off.

Growth $=34.889+0.765^{*} \mathrm{~F}-0.0624^{*} \mathrm{~F} 2(\mathrm{R} 2=0.05)$

\section{Evidence from the Case Studies}

Infosys. The formalization of the review processes at Infosys occurred in 1994 with the Strategic Planning initiative (STRAP) being put in place. This period of 13 years from its inception, coincides with the FT measured for Infosys which is also 13 years. The primary case study provides evidence to support the premise from the secondary data and in that way triangulates this research in terms of multiple types of data being used to understand the FT construct.

Trigent. The formalization of the review processes at Trigent occurred after six years from its inception in 2000, a period which coincides with the FT measured for Trigent which is also six years. The primary case study provides evidence to support the premise from the secondary data and

\begin{tabular}{|c|c|c|c|c|}
\hline \multicolumn{5}{|c|}{ Table 2. Descriptive Statistics } \\
\hline S. No. & $\begin{array}{l}\text { Growth } \\
\text { CAGR } \\
(1995-2004)\end{array}$ & $\begin{array}{l}\text { Employees } \\
(2004)\end{array}$ & $\begin{array}{l}\text { Age-Years } \\
(2004)\end{array}$ & FT-Years \\
\hline & $\begin{array}{l}\text { CAT: } \\
\text { Frequency }\end{array}$ & $\begin{array}{l}\text { CAT: } \\
\text { Frequency }\end{array}$ & $\begin{array}{l}\text { CAT: } \\
\text { Frequency }\end{array}$ & $\begin{array}{l}\text { CAT: } \\
\text { Frequency }\end{array}$ \\
\hline 1 & $\begin{array}{l}<10: \\
1\end{array}$ & $\begin{array}{l}<200: \\
8\end{array}$ & $\begin{array}{l}<10: \\
5\end{array}$ & $\begin{array}{l}4-7: \\
16\end{array}$ \\
\hline 2 & 10-25: 12 & 200-500: $\quad 14$ & 10-15: 24 & 8-10: 12 \\
\hline 3 & $25-40 \quad 18$ & 500-1000: 7 & 16-20: 13 & 11-13: 11 \\
\hline 4 & 40-55: 11 & 1000-5000: 16 & 20-25: $\quad 4$ & 14-16: 6 \\
\hline 5 & $\begin{array}{l}>55: \\
6 \\
\end{array}$ & $\begin{array}{l}>5000: \\
3\end{array}$ & $\begin{array}{l}>25: \\
2\end{array}$ & $\begin{array}{l}>16: \\
3\end{array}$ \\
\hline
\end{tabular}




\begin{tabular}{|c|c|c|c|c|c|c|c|}
\hline \multicolumn{8}{|c|}{ Table 3. Firms Examined (Period: 1995-2004) } \\
\hline $\begin{array}{l}S . \\
\text { No. }\end{array}$ & Firm & $\begin{array}{l}\text { Growth } \\
\text { (CAGR) }\end{array}$ & FT - Years & $\begin{array}{l}S . \\
\text { No. }\end{array}$ & Firm & $\begin{array}{r}\text { Growth } \\
\text { (CAGR) }\end{array}$ & $F T-$ Years \\
\hline 1 & ITC Infotech & -0.35 & 4 & 25 & Infotech Enterprises & 52.82 & 10 \\
\hline 2 & Perot Systems-TSI & 85.86 & 4 & 26 & Kale Consultants & 20.22 & 10 \\
\hline 3 & Cognizant & 71.1 & 5 & 27 & MAARS Software & 20.95 & 10 \\
\hline 4 & KPIT Cummins & 41.74 & 5 & 28 & Orient Information Technology & 32.66 & 10 \\
\hline 5 & Mahindra British Telecom & 39.13 & 5 & 29 & Birla Technologies & 34.11 & 11 \\
\hline 6 & Sierra Atlantic Software & 35.31 & 5 & 30 & DSQ Software & 30.22 & 11 \\
\hline 7 & Tata Infotech & 18.85 & 5 & 31 & Future Software & 36.34 & 11 \\
\hline 8 & ADITI & 44.1 & 6 & 32 & L\&T Infotech & 33.84 & 11 \\
\hline 9 & Geometric Software & 50.98 & 6 & 33 & Linc Software & 42.4 & 11 \\
\hline 10 & Hexaware Technologies & 31.3 & 6 & 34 & Polaris & 57.22 & 11 \\
\hline 11 & R S Software & 18.16 & 6 & $\overline{35}$ & ASM Technologies & 11.3 & 13 \\
\hline 12 & SRA Systems & 28.94 & 6 & 36 & Blue Star Infotech & 28.25 & 13 \\
\hline 13 & Trigent & 43.97 & 6 & 37 & Infosys & 55.52 & 13 \\
\hline 14 & Xansa & 23.25 & 6 & 38 & Patni Computer Systems & 42.67 & 13 \\
\hline 15 & J K Technosoft & 24.18 & 7 & 39 & Silverline Industries & 17.67 & 13 \\
\hline 16 & OrbiTech Solutions & 33.72 & 7 & 40 & Covansys & 33.6 & 14 \\
\hline 17 & Birlasoft & 37.1 & 8 & 41 & Hughes Software & 33.77 & 14 \\
\hline 18 & Hinduja TMT & 42.66 & 8 & 42 & Mascon & 55.75 & 14 \\
\hline 19 & Mastek & 27.89 & 8 & 43 & Aftek Infosys & 37.79 & 15 \\
\hline 20 & Satyam Computer Services & 58.68 & 8 & 44 & Nucleus Software & 43.44 & 16 \\
\hline 21 & Sonata & 20.84 & 8 & 45 & RAMCO Systems & 32.18 & 16 \\
\hline 22 & i-Flex & 40.9 & 9 & 46 & Zensar & 16.8 & 19 \\
\hline 23 & Mphasis BFL & 41.07 & 9 & 47 & Tata Consultancy Services & 32.39 & 21 \\
\hline$\overline{24}$ & CG-VAK & 14.25 & $\overline{10}$ & $\overline{48}$ & Softek & 10.08 & 23 \\
\hline
\end{tabular}

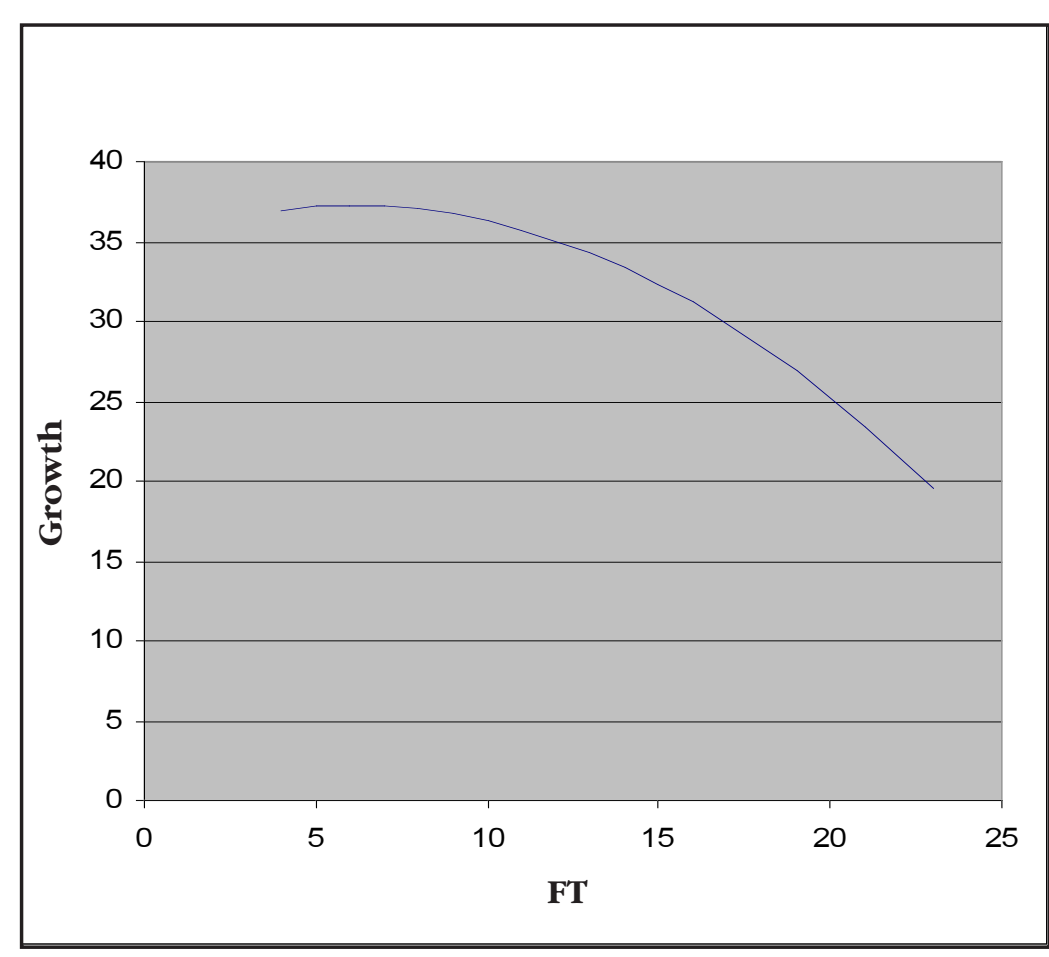

Figure 2. Growth vs. FT in that way triangulates this research in terms of multiple types of data being used to understand the FT construct.

Prologix. The formalization of the review processes at Prologix occurred in 2005-six years from its inception. This also coincided with the sharp increase in sales of its product licenses by many times its normal sales over the previous years. The primary case study provides evidence to support the premise from the secondary data and in that way triangulates this research in terms of multiple types of data being used to understand the FT construct.

\section{Furtber Research Planned}

The primary objective of this research was to establish the FT as a concept. This has been conceptualized, measured, and validated for the Indian IT services firms. However, this concept would now have to be generalized for other IT services firms across the world, before it is generalized to all types of service firms. This concept also needs to be examined for wildly fluctuating industries such as the capital machinery industry.

The larger goal of modeling the growth of firms still remains. The fit index of the model estimated in 
this research indicates that while there is an optimum FT, which seems to result in high rates of firm growth, FT alone is not sufficient to model the growth of firms.

We propose a polynomial growth modeling for future research. We have found that the 48 firms studied in this research have grown in 12 different ways, in terms of sales growth. This could be represented in 12 higher order poly- nomials of different orders. Researching these polynomial models could provide possible predictive insights into firm growth trajectories which could then be associated with their respective path dependencies. Such an approach would possibly allow us to predicate firm growth trajectory on its FT.

\section{Endnotes}

1. This research examines only the changes in subscribed capital; long-term debt has not been considered due to nonavailability of consistent data over the study period.

2. This research assumes that profits after tax are transferred to general reserves and/or carried to the balance sheet; dividends have not been considered due to non availability of consistent data over the study period.

3. Literature seems to indicate that research spend is usually internally financed, faces financial constraint, and has a relationship with cash flows, more so for new ventures and start-ups (Himmelberg and Petersen 1994; Hall and Page 2002).

4. Return on Capital Employed = Operating Profits/Capital Employed.

5. Refer to the Supplemental Material for an illustration of the measurement of the FT of Infosys Technologies Limited.

\section{References}

Bamford, C.E., Dean,T.J., and McDougall, P.P. 2000.An examination of the impact of initial founding conditions and decisions upon the performance of new bank start-ups. Journal of Business Venturing 15: 253-277.

Boeker, W.P. 1989. Strategic change:The effects of founding and history. Academy of Management Journal 32, 3: 489-515.

Brush, C.G., and Vanderwerf, P.A. 1992.A comparison of methods and sources for obtaining estimates of new venture performance. Journal of Business Venturing 7: 157-170.

Dierickx, I., and Cool, K. 1989. Asset stock accumulation and sustainability of competitive advantage. Management Science 35, 12: 1504-1511.

Gander, J.P. 1991. Managerial intensity, firm size and growth. Managerial and Decision Economics 12: $261-266$.

Hall, B.H., and Page, M.P. 2002. The financing of research and development. Oxford Review of Economic Policy 18: 35-51 (also an NBER Working Paper No. W8773).

Himmelberg, C.P., and Petersen, B.C. 1994. R\&D and internal finance:A panel study of small firms in high tech industries. Review of Economics and Statistics: 38-51.

Jovanovic, B. 1982. Selection and evolution of industry. Econometrica 50: 649-670.

Kirchhoff, B.A. 1977. Organization effectiveness measurement and policy research. Academy of Management Review 2, 3: 347-355.

Leibenstein, H. 1966. Allocative efficiency vs. X-efficiency. American Economic Review 56, 3: 392-415 (c.f. EBSCO 2001).

Leibenstein, H. 1968. Entrepreneurship and development. American Economic Review 58, 2: 72-83 (c.f. EBSCO 2001).

Leibenstein, H. 1969. Organizational or frictional equilibria, X-efficiency, and the rate of innovation. Quarterly Journal of Economics 83, 4: 600-623 (c.f. EBSCO 2001).

Leibenstein, H. 1972. Comment on the nature of X-efficiency. Quarterly Journal of Economics 86, 2: $327-331$ (c.f. EBSCO 2001).

Lippman, S.A., and Rumelt, R.P. 1982. Uncertain imitability: an analysis of interfirm differences in efficiency under competition. Bell Journal of Economics 13: 418-438.

NASSCOM. www.nasscom.org (last accessed in March, 2004).

Pennings, J.M. 1980. Environmental influences on the creation process. In John R Kimberly and Robert H Miles, eds. The organizational life cycle. San Francisco, Jossey-Bass, 134-160.

Penrose, E.T. 1959, 1984. The theory of the growth of the firm. London: Basil Blackwell Publishers. 
Romer, P.M., 1986. Increasing returns and long run growth. Journal of Political Economy 94 (October): $1002-1037$.

Slater, M.D.E. 1979. Foreword to "the theory of the growth of the firm." New Delhi: Khosla Publishing House.

Wernerfelt, B. 1984. A resource based view of the firm. Strategic Management Journal 5: 171-180.

Williamson, O.E. 1989. Transaction cost economics. In R. Schmalensee and R.D. Willig, eds., Handbook of industrial organization. North Holland,Amsterdam, 136-182.

\section{Supplemental Material Estimating the FT of Infosys}

The graphical plot presented in Figure 3 allows us to visualize the various peaks of sales growth for Infosys Technologies Limited from 1982-2004. The firm was established in 1981 and its reported financial results are available from 1982.
There are seven peaks of sales growth measured on a yearon-year (YOY) basis for the firm over the period of observation.The first peak is within the three-year period from inception and the same shall be ignored for FT computation. Among the remaining sales growth peaks, peaks 2, 5,6 and 7, in the order of occurrence, are the prominent peaks.

Let us consider peak 2 first which occurs in 1987. There is

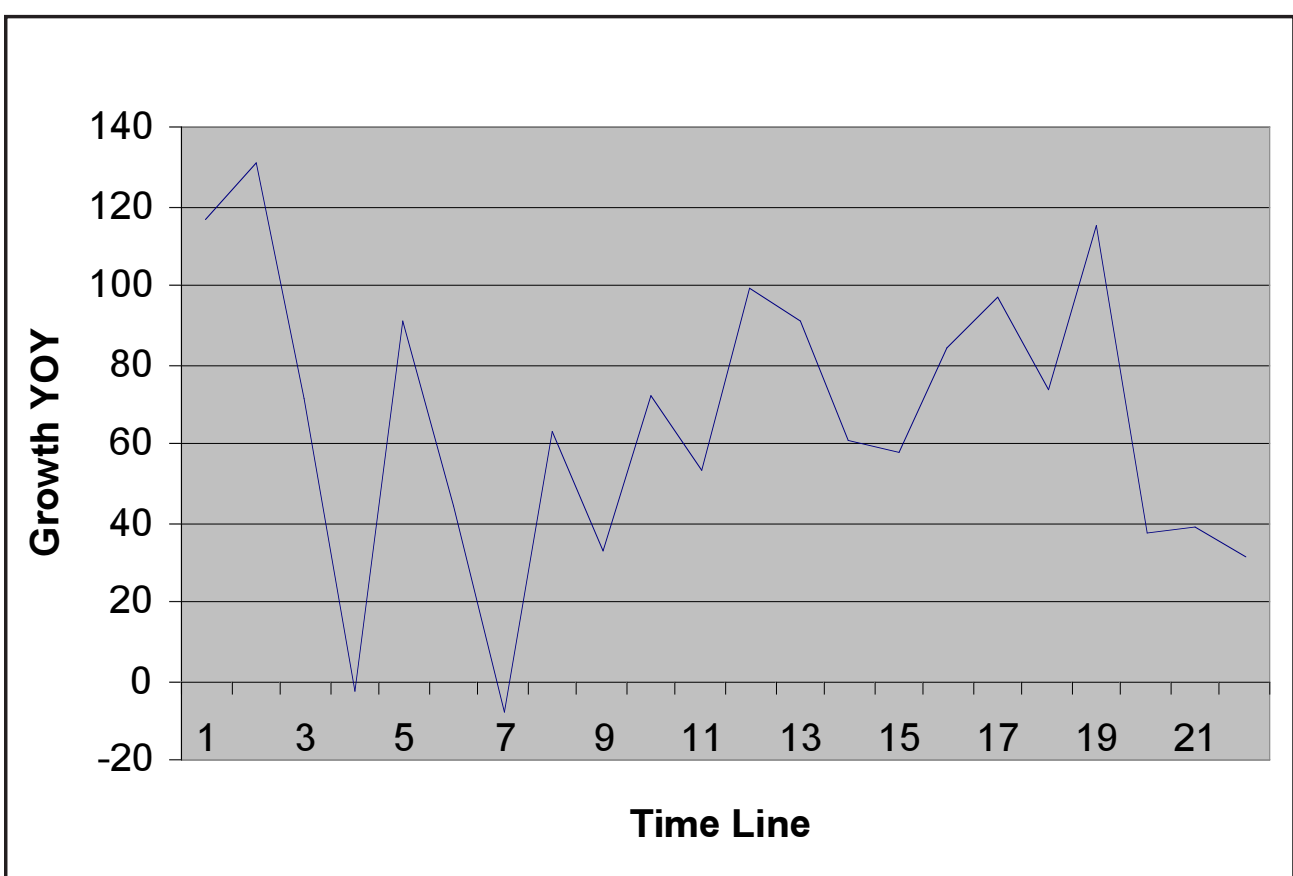

Figure 3.

Sales Growth Rate (YOY) of Infosys Technologies Limited a negative growth recorded by Infosys in 1989 and the profits decline in 1989, both of which occur within three years of 1987 ; hence this is not a stable peak for consideration of the FT.

The next prominent peak in the order of occurrence is the peak 5 which occurs in 1994. This peak satisfies all the conditions stipulated in the estimating method in terms of positive growth for three years after 1994, stable or increasing profits for three years after 1994, and stable returns on the capital employed for a period of three years from 1994.

The founding completion year is 1993 and the FT for Infosys is 13 years. The top management of Infosys agrees with the period of time it took for them to build the firm, stabilize it, and set it on a high growth path. 


\section{About the Authors}

G. R. CHANDRASHEKHAR (grchandra@hotmail.com) is an assistant professor of strategic management at the XLRI School of Management. His research interests lie at the intersection of entrepreneurship and international business with strategic management.

Mr. Chandrashekhar's research papers have been accepted by Asian Business and Management, a Palgrave journal,AGSE-BABSON 2004 conference (Melbourne, Australia), GBATA 2004 conference (Cape Town, South Africa), and the Academy of International Business (AIB) 2004 conference (Stockholm, Sweden). He was invited for the doctoral consortiums at the BKERC 2004 conference (Glasgow, Scotland) and the AIB 2004 conference (Stockholm, Sweden).

He holds a degree in electronics and communication engineering from Osmania University, Hyderabad, and an MBA from Indian Institute of Management, Bangalore.

R. SRINIVASAN (srini@iiml.ac.in) is associate professor of strategic management at the Indian Institute of Management, Lucknow. He earned his doctorate through the Fellow Programme in Management (FPM) of the Indian Institute of Management, Ahmedabad in 1998.

He has coauthored two books, Designing Knowledge Management Architecture: How to Implement Successful Knowledge Management Programmes (Response Books 2002) and Business Policy and Strategic Management: Concepts and Applications (Prentice Hall of India 2005). In addition, Dr. Srinivasan has edited the book The New Indian Industry: Structure and Key Players (Macmillan 2005), and has published a number of papers and cases in national and international journals. He is an active trainer and consultant to various private, public, and government organizations on strategic planning, management of change, and good governance. 